\title{
SINTESIS PADUAN Co-Cr MENGGUNAKAN METODE ULTRASONIK
}

\author{
Marzuki Silalahi ${ }^{1}$, Dena Nadya Rahayu ${ }^{2}$, Bambang Sugeng1, \\ Ferhat Aziz ${ }^{1}$ dan Sulistioso Giat Sukaryo ${ }^{1}$ \\ ${ }^{1}$ Pusat Sains dan Teknologi Bahan Maju (PSTBM) - BATAN \\ Kawasan Puspiptek, Serpong 15314, Tangerang Selatan \\ ${ }^{2}$ Departemen Fisika - FMIPA IPB \\ Jl. Jalan Meranti, Kampus IPB Dramaga, Bogor 16680 \\ E-mail: silalahimarzuki@gmail.com
}

\begin{abstract}
ABSTRAK
SINTESIS PADUAN Co-Cr MENGgUNAKAN METODE ULTRASONIK. Paduan $\mathrm{Co}-\mathrm{Cr}$ merupakan material tahan suhu tinggi dan tahan korosi. Penelitian ini bertujuan mensistesis serbuk paduan Co-Cr dengan metode ultrasonik, kemudian dilanjutkan dengan proses sintering dalam kapsul kaca kuarsa. Iradiasi ultrasonik yang digunakan pada frekuensi $20 \mathrm{kHz}$ dan amplitudo $40 \%$ dengan komposisi Co : $\mathrm{Cr}$ sebesar 80 : 20. Waktu perlakuan sonikasi adalah selama 0 jam, 3 jam, 6 jam, 12 jam, 24 jam, dan 48 jam dalam larutan etanol. Setelah sonikasi selama 48 jam, fasa $F C C$ dari Co mulai bertransformasi menjadi fasa $H C P$. Perlakuan ultrasonik terhadap campuran Co-Cr juga memberikan efek pengurangan ukuran partikel. Parameter kisi serbuk setelah ultrasonikasi 48 jam adalah: untuk $H C P$-Co a $=\mathrm{b}=0,25074 \mathrm{~nm}$ dan $\mathrm{c}=0,40699 \mathrm{~nm}$, untuk $F C C$-Co $\mathrm{a}=\mathrm{b}=\mathrm{c}=0,35411 \mathrm{~nm}$, dan untuk $B C C-\mathrm{Cr} \mathrm{a}=\mathrm{b}=\mathrm{c}=0.28827 \mathrm{~nm}$. Perlakuan ultrasonik selama 48 jam menhasilkan pembentukan paduan Co-Cr dengan persentasi berat sebesar 25,2124. Hasil sintering padatan Co-Cr menunjukkan parameter kisi $H C P$-Co memiliki nilai yaitu $\mathrm{a}=\mathrm{b}=0,25230 \mathrm{~nm}$ dan $\mathrm{c}=0,41223 \mathrm{~nm}$, dan $F C C$-Co $\mathrm{a}=\mathrm{b}=\mathrm{c}=0,35232 \mathrm{~nm}$. Terbentuknya microalloying CoCr diindikasikan dari hasil EDS, teramati partikel yang mempunyai komposisi $\mathrm{Co}: \mathrm{Cr}=71,25: 24,45$. Paduan $\mathrm{Co}-\mathrm{Cr}$ yang terbentuk setelah sintering pada $1300{ }^{\circ} \mathrm{C}$ adalah sebesar $15,33416 \%$ berat.
\end{abstract}

Kata kunci: Paduan Co-Cr, Ultasonik, Amplitudo, Microalloying, Struktur kristal

\begin{abstract}
SYNTHESIS OF Co-Cr ALLOY USING ULTRASONIC METHOD. Co-Cr alloys are high temperature resistant and corrosion resistant materials. This research aimed to synthesize Co-Cr alloy powder with ultrasonic method, followed by sintering process in quartz glass capsule. Ultra-sonic irradiation was used at $20 \mathrm{kHz}$ frequency and $40 \%$ amplitude with $\mathrm{Co}: \mathrm{Cr}$ composition ratio of $80: 20$. The treatment time of sonication was for $0,3,6,12,24$, and 48 hours in ethanol solution. After sonication for 48 hours, the FCC phase of Co began to transform into HCP phase. The ultrasonic treatment of the $\mathrm{Co}-\mathrm{Cr}$ mixture also provided a particle size reduction effect. The parameters of the powder grating after the 48 hours ultrasonication wereas follows : for HCP-Co $\mathrm{a}=\mathrm{b}=0.25074 \mathrm{~nm}$ and $\mathrm{c}=0.40699 \mathrm{~nm}$, for FCC-Co $\mathrm{a}=\mathrm{b}=\mathrm{c}=0.35411 \mathrm{~nm}$, and for $\mathrm{BCC}-\mathrm{Cr} \mathrm{a}=\mathrm{b}=\mathrm{c}=0.28827 \mathrm{~nm}$. The ultrasonication treatment for 48 hours resaulted Co-Cr microalloy of $25.2124 \mathrm{wt} \%$. The result of sintering of $\mathrm{Co}-\mathrm{Cr}$ solid showed that lattice parameters of HCP-Co were $\mathrm{a}=\mathrm{b}=0.25230 \mathrm{~nm}$ and $\mathrm{c}=0.41223 \mathrm{~nm}$, and FCC-Co $\mathrm{a}=\mathrm{b}=\mathrm{c}=0.35232 \mathrm{~nm}$. The formation of Co-Cr microalloying wasindicated by EDS results, it was observed that the composition of $\mathrm{Co}: \mathrm{Cr}=71.25: 24.45$. After sintering process at $1300{ }^{\circ} \mathrm{C}$ of ultrasonically treatment $\mathrm{Co}-\mathrm{Cr}$ powders, the $\mathrm{Co}-\mathrm{Cr}$ alloy portion is increased become of 15.33416 in wt\%.
\end{abstract}

Keywords: Co-Cr alloy, Ultasonic, Amplitude, Microalloying, Crystal structure 


\section{PENDAHULUAN}

Paduan berbasis kobalt merupakan material yang digunakan untuk beroperasi pada suhu tinggi, mempunyai ketahanan korosi dan biokompatibilitas yang baik [1,2]. Untuk meningkatkan sifat mekanik dan kimiawi dari paduan, dilakukan penambahan beberapa elemen, agar strukturmikro paduan $\mathrm{Co}-\mathrm{Cr}$ lebih stabil [3]. Paduan berbasis $\mathrm{Co}$ dengan variasi $\mathrm{Cr}$ diharapkan mampu meningkatkan sifat mekanik dan ketahanan korosinya sebagai bahan implan [4]. Selain stainless steel dan paduan tinanium, paduan kobalt merupakan salah satu material yang dapat diterima oleh tubuh. Paduan Logam tersebut digunakan pada implan gigi, implan penyambung tulang bahu dan pinggul, serta tulang lutut $[2,3]$.

Serbuk paduan yang berskala nano partikel, memiliki luas permukaan yang lebih besar, sehingga kapasitas penyerapan energinya lebih baik dibandingkan dengan paduan serbuk yang berukuran mikrometer [6], akibatnya paduan serbuk berukuran nanometer, dalam hal pembentukan produk dengan metode additive manufacturing [5] diperlukan suhu yang lebih rendah, juga menjadi masalah untuk mendapatkan paduan berbentuk nanometer atau mikrometer.

Metode Ultrasonik merupakan salah satu alternatif pembentukan paduan serbuk. Metode ini relatif baru dan efektif [7]. Ultrasonik dengan intensitas tinggi menjadi teknik sintesis untuk material organik dan organometalik. Parameter reaksi yang terjadi dari ultrasonik dengan intensitas tinggi yaitu peronggaan akustik: pembentukan, pertumbuhan, dan pecahnya kavitasi dalam cairan akibat adanya ledakan gelembung kavitasi $[8,9]$. Energi yang dihasilkan melalui ledakan tersebut bisa menyebabkan partikel kecil bertabrakan satu sama lain dengan energi yang besar, dan juga dapat memecah ukuran partikel menjadi lebih kecil dan homogen, hal tersebut dapat menjadi proses terbentuknya paduan [7].

Pada makalah ini akan dilakukan sintesis paduan Co-Cr menggunakan metode ultrasonik. Dengan paduan Co-Cr berbentuk nano ataupun mikro lebih memudahkan dalam pembentukan untuk bisa diaplikasikan. Fokus penelitian pada makalah ini adalah mendapatkan paduan mikrometer menggunakan metode ultrasonik.

\section{METODE PERCOBAAN}

\section{Bahan dan Alat}

Bahan-bahan yang digunakan adalah serbuk Co, Cr kemurnian 99\% dari Aldrich, Etanol absolut (kemurnian 98\%) dari Merck. Larutan etsa Kalling's No. 2 Etchant. Instrumen ultrasonik SONICS Vibra Cell dengan frekuensi $20 \mathrm{kHz}$ daya 750 watt. Sedangkan peralatan yang digunakan untuk karakterisasi sampel terdiri dari perangkat $X$-Ray Diffraction (XRD) PANalytical Empyrean Philips dengan sumber radiasi berupa $\mathrm{Cu}-\mathrm{K} \alpha$ panjang gelombang $\lambda=1,54060 \AA$, dan Scanning Electron Microscope (SEM) JEOL JSM-650LA dengan percepatan energy sebesar $20 \mathrm{keV}$ yang dilengkapi dengan Energy Dispersive Spectrometry (EDS) dan Hardness Tester.

\section{Cara Kerja}

Campuran serbuk Co-Cr dengan komposisi 80:20 persen berat diultrasonikasi dalam larutan etanol dengan perbandingan volume etanol : serbuk $\mathrm{Co}-\mathrm{Cr}$ sebesar 7 : 3 pada frekuensi $20 \mathrm{kHz}$, amplitudo $40 \%$ dengan variasi waktu selama 0 jam, 12 jam, 24 jam, dan 48 jam. Untuk sampel 0 jam dilakukan pencampuran dengan manual didalam mortar. Serbuk hasil ultrasonikasi dikompaksi lalu dikapsulasi dalam gelas kuarsa, keadaannya vakum, kemudian dilakukan proses sintering selama 2 jam pada suhu $1300{ }^{\circ} \mathrm{C}$. Secara berturut-turut masing-masing sampel diberi nama $1 \mathrm{~S}, 4 \mathrm{~S}$, $5 \mathrm{~S}$ dan $6 \mathrm{~S}$.

\section{HASIL DAN PEMBAHASAN}

Gambar 1 menunjukkan analisis $E D S$ dari serbuk Co-Cr akibat sonikasi selama 24 jam, dengan hasil analisis kandungan unsur ditunjukkan pada Tabel 1 .

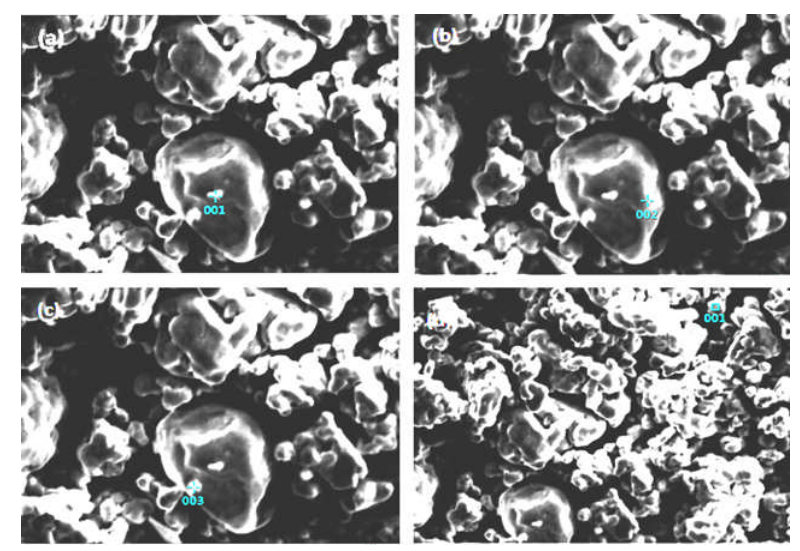

Gambar 1. Analisis SEM setelah ultrasonikasi selama 24 jam, perbesaran 4000x (a). titik 001, (b). titik 002, (c). titik 003 dan (d). Perbesaran 2000x yang diindikasi titik 001 .

Tabel 1. Data analisis EDS setelah ultrasonikasi 24 jam

\begin{tabular}{ccc}
\hline \multirow{2}{*}{ Titik analisis } & \multicolumn{2}{c}{ Massa (\%) } \\
\cline { 2 - 3 } & Co & Cr \\
\hline Titik 001(a) & 71,65 & 24,45 \\
Titik 002(b) & 92,81 & 1,60 \\
Titik 003(c) & 18,19 & 80,84 \\
Titik 001(d) & 94,40 & 1,82 \\
\hline
\end{tabular}

Dari Tabel 1 dapat dilihat adanya indikasi penyatuan partikel Co dan $\mathrm{Cr}$ (seperti terlihat pada Gambar 1) terjadi pada perlakuan untrasonik (sonikasi) selama 24 jam. 
Hasil pengamatan terhadap serbuk Co-Cr menggunakan $X R D$ tertera pada Gambar 2. Dari Gambar 2 terlihat bahwa semakin bertambahnya waktu ultrasonikasi intensitas puncak $\mathrm{Cr}$ semakin berkurang, sedangkan puncak-puncak Co tidak mengalami banyak perubahan sesuai dengan penelitian sebelumnya [11,12]. Fasa $F C C$ memiliki intensitas yang lebih rendah dibandingkan fasa $H C P$, semakin bertambahnya waktu ultrasonikasi puncak FCC meluruh meskipun perubahannya tidak signifikan. Perubahan fasa mulai terlihat setelah dilakukan ultrasonikasi selama 48 jam, puncak $F C C$ pada posisi $2 \theta$ sebesar $51,46^{\circ}$ dan puncak $B C C$-Cr pada posisi $2 \theta$ sebesar $115,66^{\circ}$ hilang. Dengan demikian bahwa fasa $F C C$ mulai bertransformasi menjadi fasa $H C P$, dan partikel $\mathrm{Cr}$ mulai masuk ke dalam matriks Co.

Gambar 2 menunjukkan pola difraksi serbuk Co-Cr dari variasi waktu ultrasonikasi: (1) 0 jam, (2) $3 \mathrm{jam}$, (3) $6 \mathrm{jam}$, (4) $12 \mathrm{jam}$, (5) $24 \mathrm{jam}$, (6) $48 \mathrm{jam}$; dan padatan CoCr: (1 s) sinter sampel 1, (4 s) sampel 4, (5 s) sampel 5 dan $(6 \mathrm{~s})$ sampel 6.

Dari penelitian sebelumnya [13], dilaporkan bahwa pola difraksi dari Paduan Co-20 Cr, tidak menunjukkan fasa $\mathrm{Co}-\mathrm{Cr}$ dengan jelas tapi yang tampak dominan adalah fasa $\mathrm{Co}$, hal ini disebabkan $\mathrm{Cr}$ dengan struktur $B C C$ larut pada Co dengan struktur HCP. Pola difraksi ini sesuai dengan hasil pengamatan pada penelitian ini, fasa $\mathrm{Co}-\mathrm{Cr}$ hasil sintesis dengan metoda ultrasonic terindikasi terbentuk paduan $\mathrm{Co}-\mathrm{Cr}$, baik dari serbuk (SEM-EDS, pola difraksi) maupun dari padatan setelah disintering $1300{ }^{\circ} \mathrm{C}$.

Tabel 2 memperlihatkan nilai ukuran kristal terhadap waktu ultrasonikasi pada Co-Cr, setelah sintering. Dari Tabel 2 diperoleh bahwa semakin lama waktu ultrasonikasi semakin kecil ukuran kristal yang terbentuk sesuai dengan pengamatan peneliti sebelumnya [7], sementara semakin besar nilai persentase tegangan-mikro. Sama halnya dengan serbuk $\mathrm{Co}-\mathrm{Cr}$, Hal ini disebabkan karena dengan semakin mengecilnya ukuran partikel seiring bertambahnya waktu ultrasonikasi maka tegangan antar partikel menjadi besar. Fasa yang dominan pada sampel padatan Co-Cr merupakan fasa $H C P$, terlihat dari intensitas difraksi sinar-X yang lebih tinggi dan secara umum setelah perlakuan ukuran kristal $H C P$ lebih besar dibanding $B C C$.

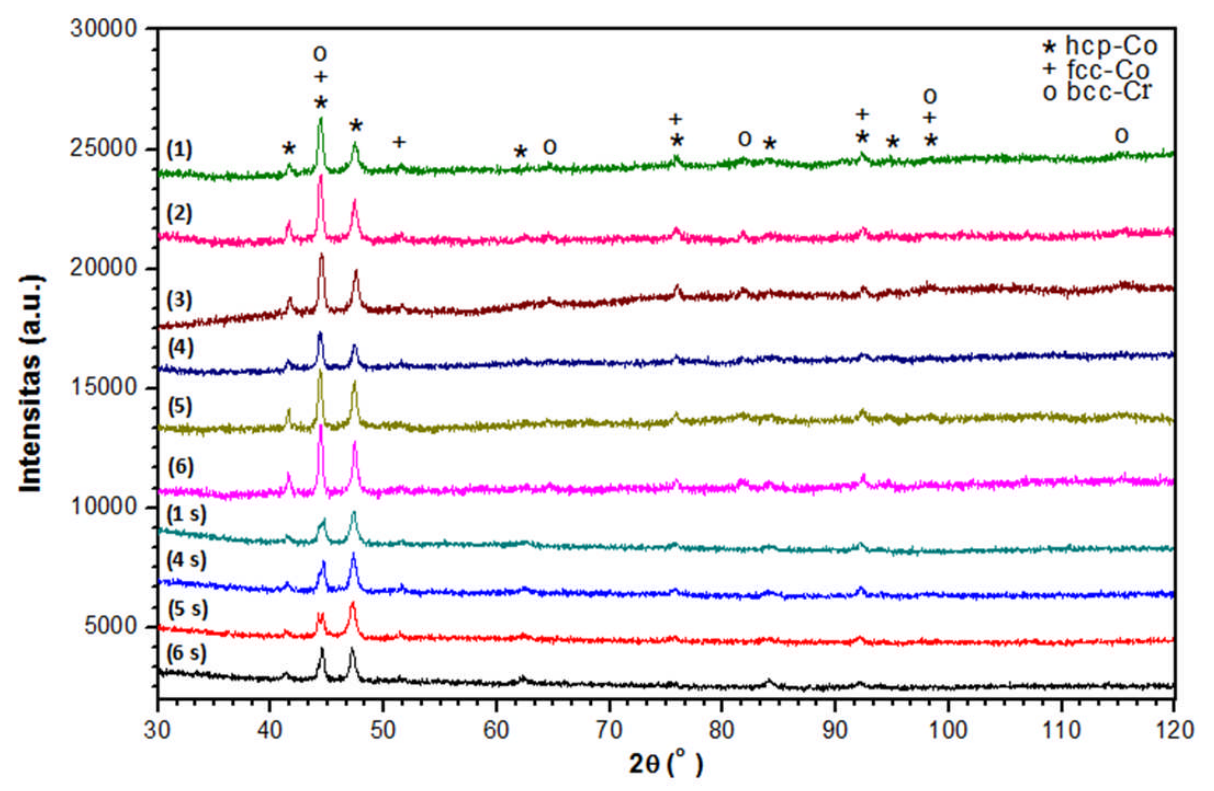

Gambar 2. Pola difraksi serbuk Co-Cr dari variasi waktu ultrasonikasi: (1) 0 jam, (2) 3 jam, (3) $6 \mathrm{jam}$, (4) $12 \mathrm{jam}$, (5) $24 \mathrm{jam},(6) 48 \mathrm{jam}$; dan padatan CoCr: (1 s) sinter sampel 1, (4 s) sampel 4, (5 s) sampel 5 dan (6 s) sampel 6.

Tabel 2. Data ukuran kristal padatan Co-Cr terhadap waktu ultrasonikasi

\begin{tabular}{|c|c|c|c|c|c|}
\hline Sampel & $\begin{array}{l}\text { Struktur } \\
\text { fasa }\end{array}$ & $\begin{array}{c}\text { No. } \\
\text { sampel }\end{array}$ & $\begin{array}{l}\text { Waktu } \\
\text { (jam) }\end{array}$ & $\begin{array}{c}\text { Tegangan-Mikro } \\
(\%)\end{array}$ & $\begin{array}{c}\text { Ukuran kristal } \\
(\mathrm{nm})\end{array}$ \\
\hline \multirow{8}{*}{ Padatan } & \multirow{4}{*}{ HCP-Co } & $1 \mathrm{~S}$ & 0 & 0.307 & 35.907 \\
\hline & & $4 S$ & 12 & 0.370 & 24.690 \\
\hline & & $5 \mathrm{~S}$ & 24 & 0.438 & 22.659 \\
\hline & & $6 \mathrm{~S}$ & 48 & 0.428 & 22.211 \\
\hline & \multirow{4}{*}{ FCC-Co } & $1 \mathrm{~S}$ & 0 & 0.298 & 34.984 \\
\hline & & $4 \mathrm{~S}$ & 12 & 0.313 & 29.197 \\
\hline & & $5 \mathrm{~S}$ & 24 & 0.355 & 23.211 \\
\hline & & $6 \mathrm{~S}$ & 48 & 0.352 & 22.850 \\
\hline
\end{tabular}


Hasil analisis refinement dengan menggunakan program Material Analysis Using Diffraction (MAUD) [10] diperoleh data seperti pada Tabel 3.

Table 3. Data kualitas refinement pola difraksi $\mathrm{Co}-\mathrm{Cr}$ terhadap waktu ultrasonikasi.

\begin{tabular}{cccc}
\hline Sampel & No. sampel & $\begin{array}{c}\text { Waktu } \\
\text { (jam) }\end{array}$ & GOF* \\
\hline \multirow{5}{*}{ Serbuk } & 1 & 0 & 1,573 \\
& 2 & 3 & 1,631 \\
& 3 & 6 & 1,846 \\
& 5 & 12 & 1,425 \\
& 6 & 24 & 1,777 \\
Padatan & $1 \mathrm{~s}$ & 48 & 1,577 \\
& $4 \mathrm{~s}$ & 12 & 1,852 \\
& $5 \mathrm{~s}$ & 24 & 1,918 \\
& $6 \mathrm{~s}$ & 48 & 1,896 \\
\hline
\end{tabular}

*Goodness of Fit (GOF): kualitas refinement program Material Analysis Using Diffraction (MAUD)

Dari hasil refinement (Gambar 4 ), diperoleh bahwa paduan Co-Cr (dengan referensi COD 15424164, $\mathrm{Co}_{0,8} \mathrm{Cr}_{0,2}$ ) adalah sebesar 25,2124\% \%erat. Hasil ini mempertegas indikasi awal paduan Co-Cr hasil EDS pada Gambar 1. Paduan Co-Cr terbentuk akibat perlakuan ultrasonik disebabkan tekanan, kavitasi dan ledakan kavitasi selama proses sonikasi, sebagaimana hasil penelitian sebelumnya [7].

Dari hasil refinement (Gambar 5 ), diperoleh bahwa paduan Co-Cr yang diperoleh sebesar 15,33416 \% berat.
Komposisi Fasa Co-Cr berkurang hasil ultrasonik berkurang pada proses pembentukan, hal ini disebabkan sebagian $\mathrm{Cr}$ teroksidasi menjadi $\mathrm{Cr}_{2} \mathrm{O}_{3}$. Dilain pihak, setelah proses sintering pada $1300{ }^{\circ} \mathrm{C}$ terjadi peningkatan intesitas difraksi secara signifikan. Posisi peningkatan Intensitas puncak difraksi pada posisi $2 \theta=47,35^{\circ}$ merupakan puncak dengan intensitas tertinggi. Adapaun posisi puncak ini merupakan milik $\mathrm{Co}-\mathrm{HCP}$ dan paduanCo $\mathrm{Co}_{0,8} \mathrm{Cr}_{0,2} \mathrm{HCP}$. hasil ini semakin mempertegas bahwa paduan Co-Cr terbentuk.

Hasil refinement program MAUD [10] ditampilkan pada Gambar 4 dan Gambar 5 didapatkan data parameter kisi terhadap variasi waktu ultrasonikasi dari ketiga fasa yang terbentuk seperti tertera pada Tabel 4. Dari Tabel 4 diperoleh bahwa parameter kisi tidak mengalami perubahan yang berarti seiring bertambahnya waktu ultrasonik memperlihatkan kestabilan parameter kisi terhadap variasi waktu ultrasonikasi pada sampel serbuk dan padatan (Gambar 6 dan Gambar 7). Data parameter kisi menunjukan bahwa perlakuan ultrasonik dan sintering tidak mempengaruhi nilai parameter kisi. Padatan paduan $\mathrm{Co}-\mathrm{Cr}$ yang telah diultrasonikasi selama 48 jam memiliki fasa tunggal yaitu $H C P$.

Sampel yang telah disinter (padatan), dilakukan uji kekerasan. Nilai kekerasan semakin meningkat seiring bertambahnya waktu ultrasonikasi yaitu dari 96,068 + 3,199 Hardness Vicker Number $(H V N)$ menjadi 129,686 $\pm 18,370 H V N$ setelah dilakukan

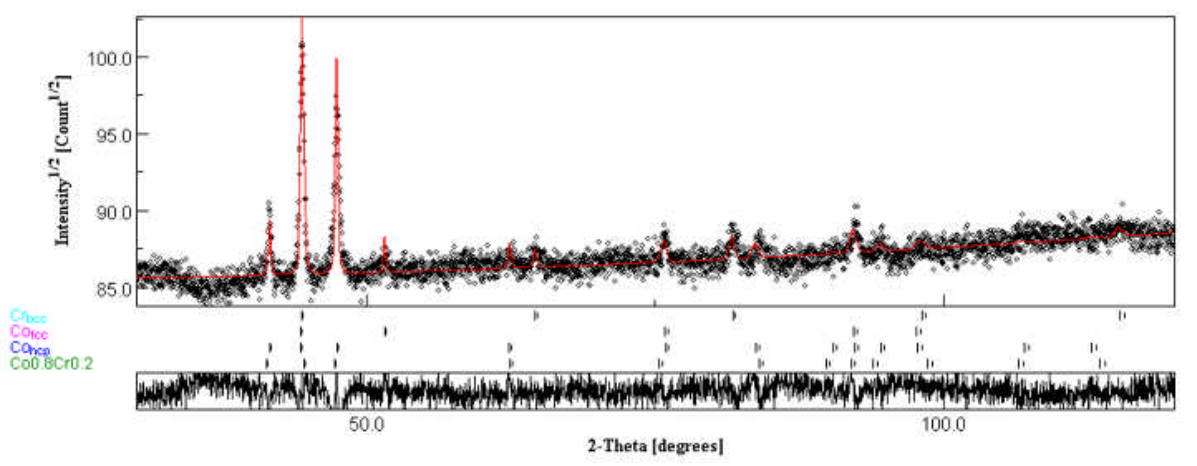

Gambar 4. Rietveld refinement dalam program MAUD dari pola difraksi XRD serbuk Co-Cr pada waktu ultrasonikasi 48 jam.

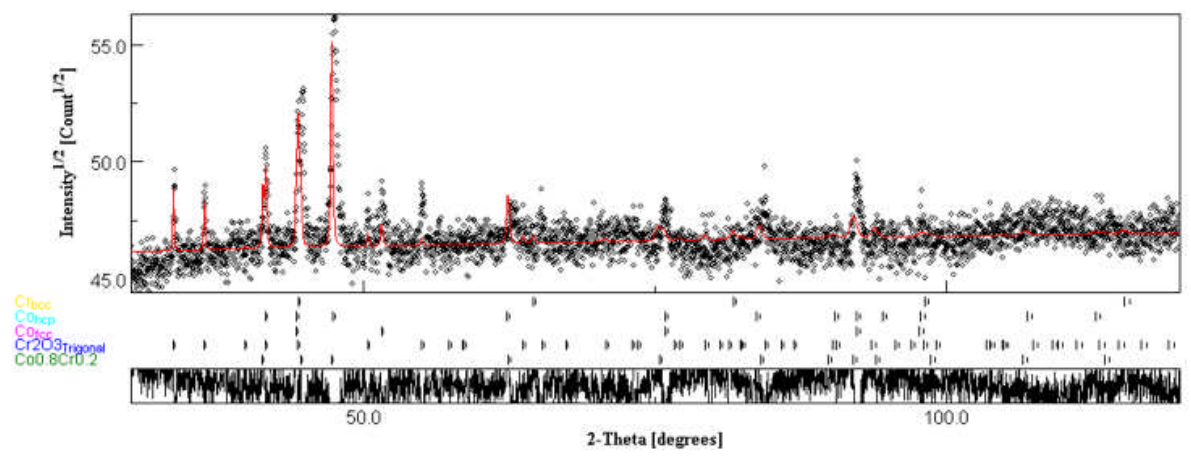

Gambar 5. Rietveld refinement dalam program MAUD dari pola difraksi XRD bulk Co-Cr waktu ultrasonikasi 48 jam 
Studi Sintesis Paduan Co-Cr Menggunakan Metode Ultrasonik (Marzuki Silalahi)

Table 3. Nilai parameter kisi referensi dan hasil refinement pada sampel 1 dan sampel 6.

\begin{tabular}{lcccccccc}
\hline \multirow{2}{*}{ Sampel } & Struktur & \multicolumn{3}{c}{ COD } & \multicolumn{2}{c}{ Sampel 1 } & \multicolumn{2}{c}{ Sampel 6 } \\
& fasa & No. ID & a (nm) & c (nm) & a (nm) & c (nm) & a (nm) & c (nm) \\
\hline Serbuk & HCP-Co & 9012950 & 0,25054 & 0,40893 & 0,25070 & 0,40725 & 0,25074 & 0,40699 \\
& FCC-Co & 9012949 & 0,35441 & & 0,35418 & & 0,35411 & \\
& BCC-Cr & 9008531 & 0,28839 & & 0,28823 & & 0,28827 & \\
Padatan & HCP-Co & 9012950 & 0,25054 & 0,40893 & 0,25130 & 0,40657 & 0,25230 & 0,41223 \\
& FCC-Co & 9012949 & 0,35441 & & 0,35227 & & 0,35232 & \\
\hline
\end{tabular}

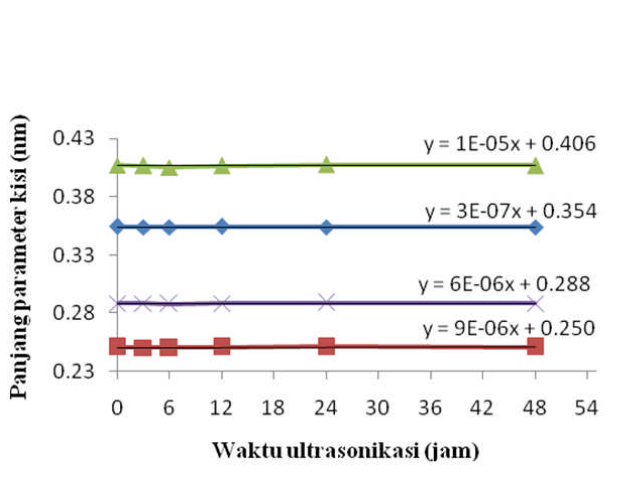

Gambar 6. Perubahan parameter kisi terhadap waktu ultrasonikasi dari serbuk $\mathrm{Co}-\mathrm{Cr}$

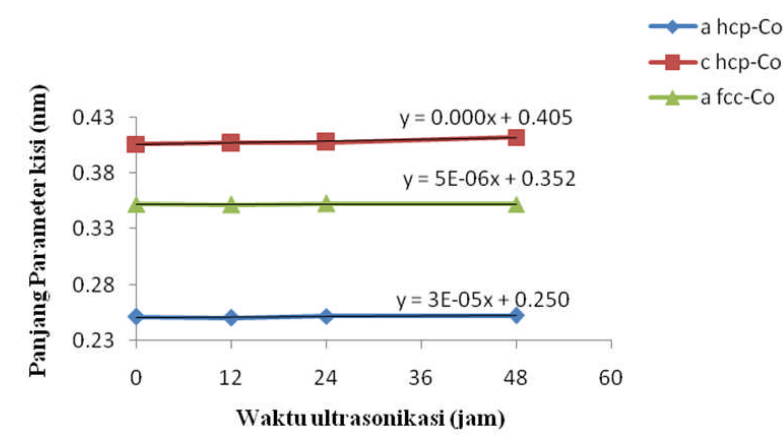

Gambar 7. Perubahan parameter kisi terhadap waktu ultrasonikasi dari padatan $\mathrm{Co}-\mathrm{Cr}$

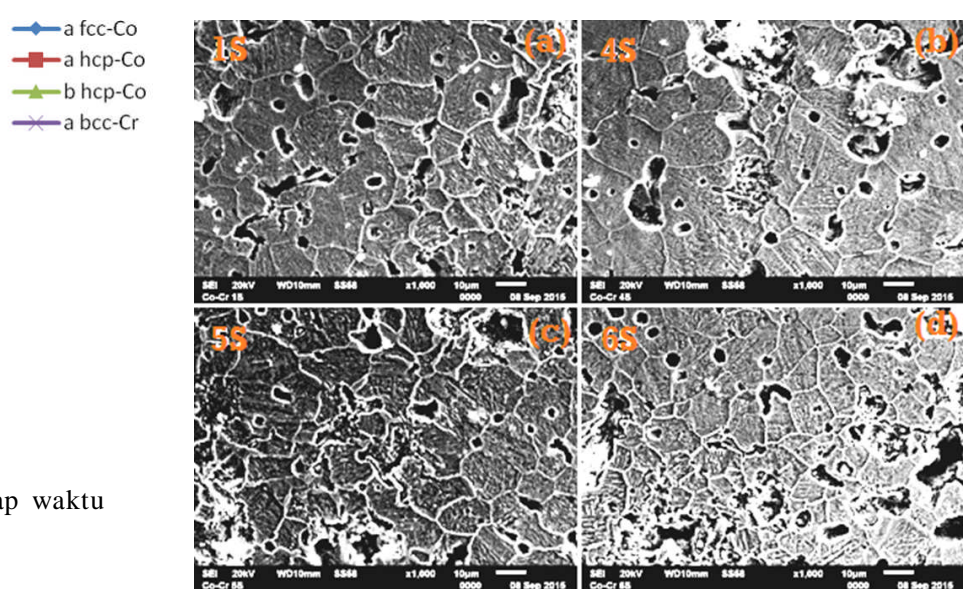

Gambar 8. Strukturmikro padatan $\mathrm{Co}-\mathrm{Cr}$ setelah sintering $1300{ }^{\circ} \mathrm{C},(\mathrm{a}) .1 \mathrm{~S},(\mathrm{~b}) .4 \mathrm{~S},(\mathrm{c}) .5 \mathrm{~S}$ dan (d). $6 \mathrm{~S}$.

ultrasonikasi selama 24 jam. Namun pada sampel 6S nilai kekerasannya menurun yaitu 110,049 $\pm 0,596 \mathrm{HVN}$ (lihat Tabel 4). pada sampel 4S disetiap titik didapatkan nilai kekerasan yang tidak jauh berbeda satu sama lain, hal tersebut menunjukan bahwa sampel 4S lebih homogen. Nilai kekerasanya menurun, diduga karena antar partikel mulai berpadu sehingga partikelnya membesar ketika disinter.

Gambar 8 merupakan morfologi strukturmikro Co-Cr hasil sintering, menggunakan SEM dengan
Co-Cr $1 \mathrm{~S}-04$
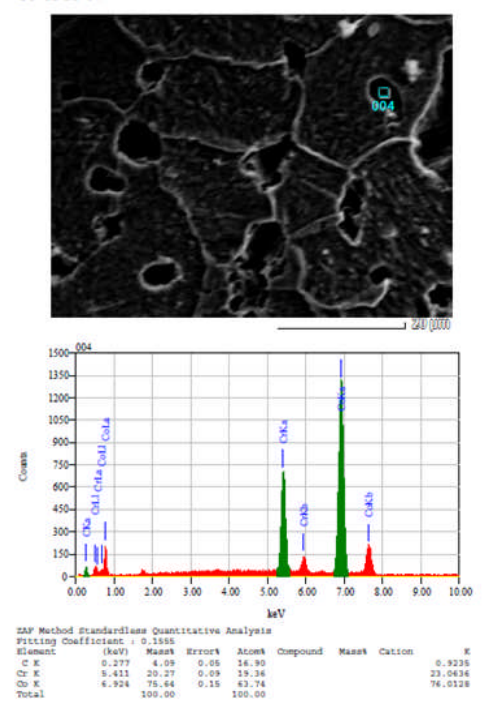

Co-Cr $4 \mathrm{~S}-03$
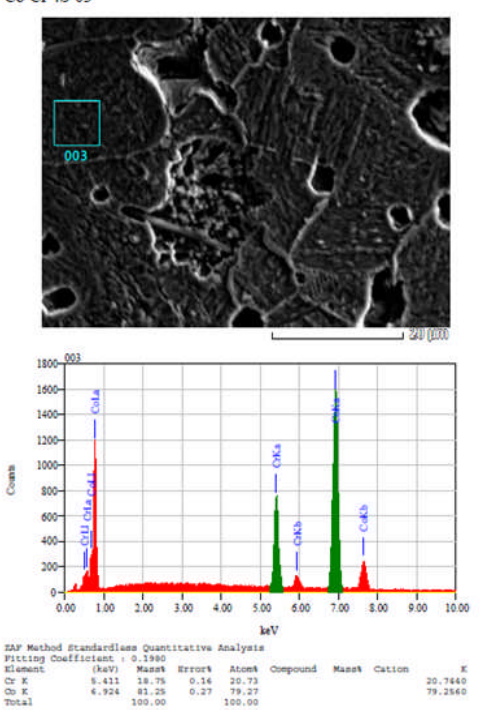

Co-Cr $5 \mathrm{~S}-01$
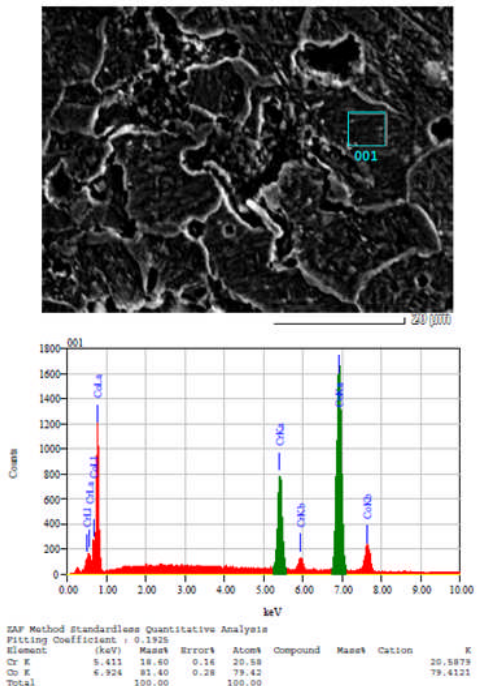

Gambar 9. Analisis SEM-EDS padatan untuk sampel (a). 1S, (b). $4 \mathrm{~S}$ dan (c). 6S. 
Tabel 4. Nilai kekerasan padatan $\mathrm{Co}-\mathrm{Cr}$ dengan ultrasonikasi berbeda.

\begin{tabular}{cc}
\hline Sampel & HVN $\pm \sigma$ \\
\hline $1 S$ & $96,068 \pm 3,199$ \\
$4 \mathrm{~S}$ & $112,080 \pm 5,046$ \\
$5 \mathrm{~S}$ & $129,686 \pm 18,370$ \\
$6 \mathrm{~S}$ & $110,049 \pm 0,596$ \\
\hline
\end{tabular}

perbesaran 1000x. Pada Gambar 8 juga terlihat batas butir yang muncul dari hasil etsa terhadap sampel, batas butir tersebut menunjukan bentuk partikel dari paduan. Dari keempat sampel diperoleh pola batas butir Co-Cr yang sama. Uji komposisi menggunakan SEM-EDS tertera pada Gambar 9. Dari Gambar 9 diperoleh bahwa pada matriks $1 \mathrm{~S}$ mencakup unsur Co dan $\mathrm{Cr}$ dengan komposisi $20,73 \%$ Cr dan 79,27 \%Co. Demikian pula pada sampel $5 \mathrm{~S}$ diperoleh komposisi Co dan $\mathrm{Cr}$ pada matriks yaitu $20,58 \%$ Cr dan $79,42 \%$ Co. Hal ini menunjukan bahwa setelah proses sintering diperoleh komposisi $\mathrm{Co}-\mathrm{Cr}$ diharapkan yaitu sekitar $20 \% \mathrm{Cr}$ dan $80 \%$ Co.

\section{KESIMPULAN}

Ultrasonikasi selama 48 jam dengan frekuensi $20 \mathrm{kHz}$ pada amplitudo $40 \%$ mengakibatkan partikel partikel Co maupun Cr mengecil dari $20 \mu \mathrm{m}$ hingga 60 $\mu \mathrm{m}$ menjadi $8 \mu \mathrm{m}$. dan terjadi transformasi struktur setelah ultrasonikasi fasa $F C C$ mulai bertransformasi menjadi fase $H C P$. Perlakuan ultrasonik selama 48 jam menhasilkan pembentukan paduan $\mathrm{Co}-\mathrm{Cr}$ dengan persentasi berat sebesar 25,2124. Fasa Co-Cr padat hasil sintering adalah $H C P$, dengan nilai $\mathrm{a}=\mathrm{b}=0,25230 \mathrm{~nm}$ dan $\mathrm{c}=0,41223 \mathrm{~nm}$, dan $F C C-\mathrm{Co} \mathrm{a}=\mathrm{b}=\mathrm{c}=0,35232 \mathrm{~nm}$. Setelah proses sintering pada serbuk Co-Cr yang diultrasonikasi 48 jam diperoleh komposisi Co-Cr paling mendekati dengan komposisi yang diharapkan sesuai komposisi awal yaitu dengan komposisi 20,58 \% massa $\mathrm{Cr}$ dan 79,42 \%massa Co. Paduan Co-Cr yang terbentuk setelah sintering pada $1300{ }^{\circ} \mathrm{C}$ adalah sebesar $15,33416 \%$ berat .

\section{UCAPAN TERIMAKASIH}

Penulis mengucapkan terimakasih kepada Bapak Tri Hardi untuk penggunaan software $M A U D$, Bapak Bambang Sugeng untuk Karakterisasi XRD, Bapak Rohmad Salam untuk proses sintering, Bapak Agus Sujatno untuk karakterisasi sampel menggunakan SEM.

\section{DAFTAR ACUAN}

[1]. Z. Guo, X. Pang, Y. Yan, K. Gao, A. A. Volinskyd and T.Y. Zhang. "CoCrMo Alloy for Orthopedic Implant Application Enhanced Corrosionand Tribocorrosion Properties by Nitrogen Ion Implantation." Applied Surface Science. vol. 347, pp. 23-34, 2015.
[2]. S.G. Sukaryo, A. Purnama and H. Hermawan. "Structure and Properties of Biomaterials." in. Biomaterials and Medical Devices. Switzerland: Springer International Publishing.

[3]. O. Sahin, S. Uzunoglu and E. Sahin. "Mechanical Characterization of CoCrMo Alloys Consisting of Different Palladium Ratios Produced by Investment Casting Method." Acta Physica Polonica A, vol. 128, 2015.

[4]. S.G. Sukaryo, B. Bandriyana and B. Siswanto. "Sputtering of Titanium in Co-Cr-Mo Alloys for orthopaedic Implant materials." Advanced Materials Research, vol. 1123, pp. 201-204, 2015.

[5]. W. J. Sames, F. A. List, S. Pannala, R. R. Dehoff and S. S. Babu. "The Metallurgy and Processing Science of Metal Additive Manufacturing." International Materials Reviews, vol. 61, Issue 5, 2016.

[6]. Insani A, Suwarno H, Wahyuadi J, Adi WA, Siradj ES. "Studi Difraksi Sinar-X Pada Paduan Mg-CoNi yang Dibuat dengan Metode Pemaduan Mekanik. Mechanical Alloying." Indonesian Journal of Material Science. pp. 35-39, 2006.

[7]. M. Silalahi, A. Dimyati, S. Harjanto, P. Untoro and B. Suharno. Microalloying of Fe-Cr By Using Ultrasonic Irradiation. International Journal of Technology, vol. 5, no. 2, pp.169-182, 2014.

[8]. N. Q. Tuan, H. Puga, J. Barbosa, and A. M. P. Pinto. "Grain Refinement of Al-Mg-Sc Alloy by Ultrasonic Treatment." Met. Mater. Int., vol. 21, no. 1,pp. 72-78, 2015.

[9]. Y. S. Yang, J. C. Wang, T. Wang, C. M. Liu and Z.M. Zhang. Effect of Ultrasonic Treatment on Microstructures of AZ91 Alloy. Transactions of Nonferrous Metals Society of China. vol. 24, Issue 1, pp. 76-81, 2014.

[10]. Computational Thermodynamics. 2011. CobaltChromium (Co-Cr) Phase Diagram. Calculation of Phase Diagrams using CALPHAD Method [internet]. [diunduh 19 Februari 2015.

[11]. E. Dobruchowska, M. Paziewska, K. Przybyl, K. Reszka. "Structure and Corrosion Resistance of Co-Cr-Mo Alloy Used in Birmingham Hip Resurfacing system." Acta of Bioengineering and Biomechanics, vol. 19, no. 2, 2017.

[12]. S.G.Sukaryo, B. Bandriyana dan Pius Sebleku. "Pengaruh Penambahan Molibdenum Terhadap Morfologi Struktur Mikro, Sifat Mekanik dan Ketahanan Korosi paduan $\mathrm{Zr-Nb}$ untuk Material Implan.” J. Metalurgi, vol. 29, no.1, 2014.

[13]. A.L.R. Ledesma, H.F. Lopez and J.A.J. Islas. "Evaluation of Chill Cast Co-Cr Alloys for Biomedical Applications." Metals, vol. 6, no. 8, pp. 188, 2016. 